\title{
The Role of FELDA and KESEDAR in the Development of Land in the District of Gua Musang: A Comparison the Socio-Economic Level of the Settlers
}

\author{
Fauzi Hussin ${ }^{1} \&$ Hussin Abdullah ${ }^{1}$ \\ ${ }^{1}$ School of Economics, Finance and Banking, College of Business, Universiti Utara Malaysia, 06010 Sintok, \\ Kedah, Malaysia \\ Correspondence: Fauzi Hussin, School of Economics, Finance and Banking, College of Business, Universiti \\ Utara Malaysia, 06010 Sintok, Kedah, Malaysia. Tel: 60-4928-3549. E-mail: fauzi@uum.edu.my
}

Received: April 13, 2012 Accepted: May 28, 2012 Online Published: July 30, 2012

doi:10.5539/sar.v1n2p284

URL: http://dx.doi.org/10.5539/sar.v1n2p284

\begin{abstract}
The South Kelantan Development Authority (KESEDAR) and the Federal Land Development Authority (FELDA) are the two main agencies that develop land schemes in the district of Gua Musang, Kelantan. The nine land schemes developed by FELDA are Kemahang 3, Chiku 1, Chiku 2, Chiku 3, Chiku 5, Chiku 6, Chiku 7, Perasu, and Aring 1. KESEDAR also developed eleven land schemes namely Paloh 1, Paloh 2, Paloh 3, Chalil, Lebir, Meranto, Sungai Terah, Renok Baru, Jeram Tekoh, Limau Kasturi, and Sungai Asap. A large part of the schemes under the FELDA was planted with oil palm (84.7\%) while the rest was planted with rubber trees. On the other hand, most of the land schemes under KESEDAR were planted with rubber (67\%), while the remainder were planted with oil palm. The question that arises is to what extent is the role of both the agencies in advancing the standard of living of the settlers? What are the problems faced by the settlers and their implications regarding their socio-economic level? This paper will discuss the role played by KESEDAR and FELDA in advancing the standard of living of the settlers as well as identifying the problems faced by the settlers under the two agencies. The study found that many settlers earned between RM600 - RM1200 per month despite the efforts undertaken by FELDA and KESEDAR to improve the living standards of the settlers. The main problems faced by the settlers are: palm oil prices are volatile; oil palm trees are old, the old age of the settlers, and the settlers' chidren migrating to the city.
\end{abstract}

Keywords: KESEDAR, FELDA, settlers' standards of living, socio-economic, Malaysia

\section{Introduction}

In the past, the rural community practiced subsistence agriculture and agriculture in the form ordinary farming as sources of their income. According to Ness (1967), Lim (1977) and K.K. Hong (1984) both these types of agriculture were practised as a result of the British rule in Malaya between 1874 and 1955. Such agricultural practices produced low yields, while the use of land for agriculture was small (Naziruddin, 1990). As a result, people lived below the poverty line because at that time no serious efforts were made to develop the sector they were involved in.

The Ministry of Rural and Regional Development has the goal of overcoming the problem of extreme poverty among the population by 2010. Currently, the number of people included in the category of hardcore poor in the country is 48,134 . As a result of the efforts of the government, from June to December 2006, 3,830 people were successfully removed from the group of hardcore poor. Until March 2007 of the 48,134 poor people, the government had successfully reduced the rate to 44,304 people and the figure will continue to be reduced (Dakian, 2008).

In an effort to eradicate poverty among the rural population, the government implemented a project known as agropolitan development, that is, new growth center based on agriculture in rural areas. The project created farming areas which were centrally managed with the participants having a say in the form of shares, homes and land to carry out commercial cultivation. In relation to this various agencies and relevant government departments were founded to help the farmers, especially in the rural areas to increase their productivity. Among the agencies involved in the development of the rural communities in the district of Gua Musang, Kelantan, Malaysia are the 
Federal Land Development Authority (FELDA) and the South Kelantan Development Authority (KESEDAR).

The main objective of establishing Felda was to develop new land to make agricultural estates more productive, create effective farm management among the settlers in terms of cleanliness of the estates and production of maximum yield and quality. In addition, FELDA was to encourage the growth of a developed and disciplined society that could improve the living standards and create an excellent and professional management mechanism oriented towards social development.

KESEDAR seeks to balance the composition of the population in the south and the northern regions of Kelantan, in addition to eradicating poverty and restructuring the society. The importance of development in the regions of South Kelantan has encouraged the federation to establish KESEDAR so that development could be balanced among the regions in the country.

\section{Background}

Gua Musang District is located in the south of Kelantan and is quite separated from the central state administration in Kota Bharu. Before 1976, this area was placed under the administrative centre of the Ulu Kelantan District covering Kuala Krai and Gua Musang. The administrative centre at that time was located in Kuala Krai. A small District Office was established in Gua Musang in 1950 headed by an Assistant District Officer and a few assistants. The establishment of the small office was to solve the people's problems. In 1953, the small office was closed. Gua Musang was given the status of a Sub-District in 1976. In September 1977, the Gua Musang Sub-District was upgraded to a Full-District. It was the ninth district in the state of Kelantan.

Gua Musang is an area where most people are from the settler community. This area is home to two large agencies, FELDA and KESEDAR that open the land schemes. FELDA was given the responsibility of developing nine land schemes, namely Kemahang 3, Chiku 1, Chiku 2, Chiku 3, Chiku 5, Chiku 6, Chiku 7, Perasu, and Aring 1. Almost the entire land scheme is planted with oil palm. However, there were also rubber plantations in Perasu in 2008 and in Chiku 3 in April 2009. The overall land area the FELDA oil palm plantation in Gua Musang was 10,552.50 hectares in 2008 and 8,867.23 hectares in 2009. Comparatively, in 2008 there was a total of 432.52 hectares of rubber plantations, which decreased to 180.66 hectares by April of 2009 .

Table 1. FELDA Gua Musang: Acreage of oil palm plantations (2008)

\begin{tabular}{cccc}
\hline \multirow{2}{*}{ Scheme } & \multicolumn{2}{c}{ Acreage of crops (hectare) } & \multirow{2}{*}{ Production (M/tonnes) } \\
\cline { 2 - 3 } & Planted & Harvested & \\
\hline Kemahang 1 & 1957.15 & 1957.15 & $23,877.15$ \\
Chiku 1 & 1806.04 & 1806.04 & $28,611.92$ \\
Chiku 2 & 1204.74 & 1204.74 & $20,665.12$ \\
Chiku 3 & 788.40 & 788.40 & $12,261.56$ \\
Chiku 5 & 1217.63 & 1217.63 & $17,104.71$ \\
Chiku 6 & 832.56 & 832.56 & $13,886.43$ \\
Chiku 7 & 1106.85 & 1106.85 & $19,226.22$ \\
Perasu & 806.67 & 806.67 & $11,684.57$ \\
Aring & 832.46 & 832.46 & $11,586.64$ \\
Total & 10552.5 & 10552.5 & $158,904.32$ \\
\hline
\end{tabular}

Source: FELDA Gua Musang office, June 2009.

As shown in Table 1, the acreage of the oil palm plantations and the total production of the Gua Musang FELDA land scheme. In 2008, the total oil palm production varied according to the size of the planted area. Although Chiku 1 had a smaller area compared to Kemahang 1 the production higher at 28,611.92 tonnes. The least amount of farm produce was from the Aring land scheme with 11,586.64 tonnes. In 2008, Felda Gua Musang had a high total yield of $158,904.32$ tonnes.

Land schemes involved in rubber cultivation under the FELDA land schemes were Perasu and Chiku 3. Perasu recorded a larger planted area compared to Chiku 3 and obtained production of 210,346 kg. However, that 
plantation underwent the replanting process in 2009.

KESEDAR consists of eleven land schemes in the district of Gua Musang. Among the land schemes are Paloh 1, Paloh 2, Paloh 3, Chalil, Lebir, Meranto, Sungai Terah, New Renok, Jeram Tekoh, Limau Kasturi, and Sungai Asap. The overall acreage of oil palm estates in the KESEDAR land scheme is 779,637 hectares. Oil palm is widely cultivated in only four land schemes: Paloh 1, Paloh 2, Paloh 3, and Chalil. In the other land schemes oil palm is cultivated on a small scale. Rubber is mostly grown in the Meranto, Sungai Terah, New Renok, Jeram Tekoh, Limau Kasturi, and Sungai Asap land schemes. The number of settlers in KESEDAR was estimated at nearly 3,500 people in 2008 .

Each settler is given a total of ten acres for the farm and a house. Therefore, the settlers' main occupation and income come from palm oil and rubber. The income derived each month covers the cost of living expenses and schooling for their children. The migration of the settlers from the original villages to the land schemes has changed their lives from that of poor villagers to that of settlers who obtain higher incomes. Settlers today can feel proud that they enjoy living in the land schemes as they own property such as vehicles, and house furnishings, have adequate water and electricity supply and other basic amenities than ever before.

Table 2. KESEDAR Gua Musang: Acreage planted with oil palm and rubber (2008)

\begin{tabular}{cccc}
\hline \multirow{2}{*}{ Scheme } & Number of settlers & \multicolumn{2}{c}{ Category of crops (hectares) } \\
\cline { 3 - 4 } & & palm oil & rubber \\
\hline Paloh 1 & 267 & 1203.88 & 429.70 \\
Paloh 2 & 302 & 1113.80 & 480.86 \\
Paloh 3 & 315 & 1420.14 & 942.86 \\
Chalil & 188 & 1136.80 & 462.59 \\
Lebir & 189 & - & 473.21 \\
Meranto & - & - & - \\
Sungai terah & 357 & 12 & 910.67 \\
Renok baru & - & - & - \\
Jeram tekoh & 356 & 182.66 & 1655.60 \\
Limau kasturi & 446 & - & 3895.0 \\
Sungai asap & 250 & - & 1377.40 \\
\hline
\end{tabular}

Source: KESEDAR office in every land scheme, June 2009.

Table 2 shows that only land schemes in Paloh 1, Paloh 2, Paloh 3, Chalil and Jeram Tekoh are planted with oil palm. As far as rubber is concerned, almost all the land schemes under KESEDAR grow rubber, except Meranto and Renok Baru which have been cleared for the replanting oil palm. The number of settlers in a land scheme depends on the land area planted in each land scheme. Land schemes that have large plantations have a larger number of settlers.

Table 3 above shows the total revenue earned in the four regions, namely Paloh 1, Paloh 2, Paloh 3 and Chalil. These land schemes have a higher acreage of oil palm plantations than the other land schemes that grow oil palm. From the table, it can be seen that the total revenue fluctuates where 2008 recorded the highest revenue for all these areas, while the lowest total revenue was recorded in 2005.

However, the agriculture sector is not stable in terms of the income of the settlers because the prices of commodities such as palm oil and rubber are always volatile. Palm oil production is seasonal and other factors such as the age of the trees and their care affect the monthly income of the settlers. In addition, there are also external factors such as market demand for palm oil which decreases the income of the settlers. Palm oil has to compete with other vegetable oils, namely soya oil, while natural rubber had to compete with synthetic rubber when it was introduced in the market. This situation is more detrimental to the settlers because their livelihood diminishes. During the economic crisis, many settlers leased their farms to outsiders. Studies made by FELDA revealed that the living standards of those who leased their land were very bad (Mazlan, 2003). 
The objective of this study is to discuss the role played by KESEDAR and FELDA in improving the standard of living of the settlers as well as identifying the problems faced by the settlers under the two agencies.

Table 3. KESEDAR Gua Musang: Oil palm yield (2008)

\begin{tabular}{cccccc}
\hline \multirow{2}{*}{ Year } & \multicolumn{4}{c}{ Total revenue for the region } \\
\cline { 3 - 6 } & & Paloh 1 & Paloh 2 & Paloh 3 & Chalil \\
\hline \multirow{2}{*}{2004} & M/tonne & 3255.21 & 2929.69 & - & 1824.62 \\
& RM & $560,509.92$ & $504,638.95$ & - & $314,290.70$ \\
\multirow{2}{*}{2005} & M/tonne & 2901.30 & 2611.20 & 716.70 & 1164.88 \\
& RM & $397,632.17$ & $357,864.95$ & - & $159,646.80$ \\
\multirow{2}{*}{2006} & M/tonne & 4295.29 & 3865.76 & 6979.80 & 2495.44 \\
& RM & $1,276,062.90$ & $1,148,456.31$ & $2,073,588.46$ & $741,355.85$ \\
2007 & M/tonne & 5855.69 & 5270.12 & 6954.89 & 5255.53 \\
& RM & $2,475,289.67$ & $2,227,760.28$ & $2,939,938.31$ & $2,221,592.86$ \\
2008 & M/tonne & 6840.62 & 6156.56 & 6962.62 & 5822.85 \\
& RM & $3,588,675.74$ & $3,229,809.21$ & $3,652,678.48$ & $3,054,740.73$ \\
\hline
\end{tabular}

Source: KESEDAR office in every land scheme, June 2009.

\section{Literature Review}

Abdullah (1984) indicated that lower socio-economic problems can be regarded as a social disease and the main enemy to national development plans. To eradicate poverty, the government has created a philosophy called the New Economic Policy. This policy has two main goals; eradicating poverty and restructuring society. In his opinion, there must no poverty in future.

From an economic standpoint, Smith (1963) believes that low socio-economic status is the situation where there is a lack of basic needs such as food, clothing, and shelter. The phenomenon of low socio-economic status is not a purely an economic issue. Thus, many researchers have included non-economic elements in the concept of low socio-economic status. Through the biological approach, that is, a concept of "enough to live", have the poor can be identified by their approach which is not sufficient to meet the minimum requirements to maintain physical efficiency.

Realising that the experience of economic development in the Third World countries has failed to bring benefits to people of the low socio-economic class, the idea about development began to shift from employment issues to the existence of 'the redistribution of growth' leading to development that is based on 'basic needs' which emphasize the importance of meeting basic human needs (Khairuddin \& Giak, 1984).

In Third World countries, because there is a strong association between low socio-economic problems and problems of fulfilling basic needs, it is difficult to separate the solution to both problems. The concept of basic needs clearly refers to a specific objective, while the concept of low socio-economic status includes a broader programme of basic needs. Therefore, efforts to erradicate low socio-economic status is often viewed in terms of 'help' to raise real income. Conversely, when the goal to achieve fulfils the basic needs, actions taken will involve the income of the poor groups, as well as the opportunities to obtain important social services. In other words, the concept of basic needs emphasises more on what should be given to the lower socio-economic class than the general income (Shamsul, 1984). Silock (1963) stated the rapid population growth in rural areas that causes the increase in members of the family to depend on the family head. The lack of land or uneconomical land size which cause underemployment and unemployment as well as the lack of capital leads to the poverty of the people in the rural areas.

According Za'ba (1975) poverty among the Malays in the colonial period was based on two factors; material poverty and spiritual poverty. The main factor that caused the material poverty was the lack of employment opportunities. This situation occurred because at that time employment opportunities in Malaya still undeveloped. 
Ayob (1994) states that the farmers were the poorest in society, particularly in developing countries. He said that although the agricultural sector had received allocations since independence, poverty among small farmers could not be eliminated altogether. Poverty in the rural areas was due to the size of the land, uneconomical crops, low technology, the system of land tenancy and limited opportunities to increase revenue. According to World Bank (1989) the experience of developing countries showed that economic growth does not always translate into the elimination of poverty and the improvement of income distribution. In 1990, poverty still hit the developing countries and it was estimated that one million people were affected by poverty, especially in South Africa, Africa, Sub-Saharan and Latin America. Policies and strategies to address the poverty experienced by the developing countries varied according to the phases of development. In the 1950s and 1960s, the emphasis was on growth to reduce poverty and improve the living standards. The spillover from economic growth was less effective to overcome poverty; so another approache was tried in 1970 which emphasized the provision of health, education, and nutrition as well as land reforms and integrated rural development.

The settlers suffered because of the decline of agricultural produce which made difficult the lives of 168,750 settlers in FELDA and 35,815 families of smallholders as well as around 33,000 FELCRA settler families. Around 1997 and 1998 the price of palm oil was RM400 per tonne and in 2000 it had reached the lowest level of RM60 per tonne. For FELDA settlers, the income was slightly better than the small farmers in the villages because the FELDA palm oil was of a higher quality compared to that of the smallholders and could be sold at about RM100 per tonne which was still much lower (Jamaludin, 2001).

Replanting of new oil palms to replace the old palm trees which were uneconomical was believed to be an economically practical strategy for enhancing the productivity of palm oil. Higher productivity would ensure the continuation of the oil palm industry and could compete when the price of palm oil was at low levels. Harvesting oil palm seeds from high trees would surely incur high costs. The cost of harvesting for a tree high was between RM28 to RM35 compared to between RM20 to RM23 for a low tree (Omar et al., 2001).

Changes in the structure of Malaysia's economy from agriculture to industry resulted in the migration of labour from the agricultural to the industrial sector. This resulted in the shortage of domestic labour in the agricultural sector which was so serious that about 1.5 million foreign workers were needed (Ming \& Chandramohan, 2002). Ibrahim (1994) states that the lack of attractive power and good opportunities in the FELDA land schemes caused people, especially the settlers' children to move out to places that they felt was appropriate to their needs and youthfulness. This resulted in the plantation sector facing a local labour shortage.

Arshad (2004) states that if a comparison is made between the agricultural and the other sectors the wages, the incentives and the work environment in the agricultural sector was not very competitive. This directly hampered the government's attemps to attract young people to work in the agricultural sector. Generally, village youths prefer to work in factories than on farms. The factor that most of the nation's workforce is highly qualified also complicates the situation where university graduates prefer to work in sectors that are considered more appropriate to their qualifications.

According to Tadaro (1997) the economic transformation from traditional sectors (agricultural) to the industrial sector affects the distribution of human resources in the economy and creates more opportunities for productive employment.

\section{Methodology and Data}

The population of this study was the settlers in the FELDA and KESEDAR land schemes in the Gua Musang district as respondents. A total of 250 questionnaires were collected from the respondents. The survey respondents were heads of households of each family of settlers as the sample to represent all the settlers in the FELDA and KESEDAR land schemes in Gua Musang, Kelantan, Malaysia.

The questionnaire contained information such as demographic factors, types of crop cultivated, farm income, ancillary income (if any), the overall income, facilities and assistance available and the problems that arose. This information was derived from the responses of the respondents through the questionnaire. Besides face-to-face interviews were also conducted to obtain additional information from the KESEDAR and FELDA officers, and reports that might add further information.

\section{Results}

Table 4 shows the estimated farm income earned by the respondents each month. The estimated total income from the farm produce was classified into eight categories. The majority of the respondents in both the land schemes earned between RM601 to RM1200 of 71 respondents from the Felda land schemes, and 76 respondents from the ground KESEDAR plan. For the category of income between RM301 to RM600, it was found that there 
were 22 respondents from the FELDA land schemes, while 33 were from the KESEDAR land schemes.

Table 4. Total farm revenue of FELDA and KESEDAR settlers

\begin{tabular}{cccc}
\hline \multirow{2}{*}{ Total Farm Revenue } & FELDA & KESEDAR & \multirow{2}{*}{ Total } \\
\cline { 2 - 3 } & Number & Number & \\
\hline Less than RM300 & 0 & 1 & 1 \\
RM301 - RM600 & 22 & 33 & 55 \\
RM601 - RM900 & 43 & 40 & 83 \\
RM901 - RM1200 & 28 & 36 & 64 \\
RM1201 - RM1500 & 20 & 15 & 35 \\
RM1501 - RM1800 & 0 & 8 & 8 \\
RM1801 -RM2100 & 0 & 0 & 0 \\
More than RM2101 & 4 & 0 & 4 \\
Total & 117 & 133 & 250 \\
\hline
\end{tabular}

Table 5 shows the length of time the respondents were settlers in the FELDA and KESEDAR land schemes. The majority of the respondents in the FELDA land schemes had between 20 to 23 years that is a total of 58 compared to 46 respondents from the KESEDAR land schemes. The settlers in the KESEDAR land schemes had settled there between 24 to 27 years that is a total of 40 respondents compared to 29 respondents from the FELDA land schemes. The conclusion that can be made is that most settlers in each land schemes have been living for a long time in the area and cultivating oil palm and rubber. This period of stay is similar to the age of the oil palm and rubber trees. During this period of more than 20 years, about the trees have grown old, produce less and it is time for replanting. The income of most of the settlers' will decrease if the oil palm and rubber plantations are not replanted.

Table 5. The length of time being a settler

\begin{tabular}{clll}
\hline \multirow{2}{*}{ The length of time being a settler } & FELDA & KESEDAR & Total \\
\cline { 2 - 3 } & Number & Number & \\
\hline $12-15$ years & 6 & 14 & 20 \\
$16-19$ years & 24 & 25 & 49 \\
$20-23$ years & 58 & 46 & 104 \\
$24-27$ years & 29 & 40 & 69 \\
28 years and above & 0 & 8 & 8 \\
Total & 117 & 133 & 250 \\
\hline
\end{tabular}

Table 6 shows the total revenue earned by the respondents in KESEDAR and FELDA Gua Musang. The total income includes income from farm produce and ancillary income. The table shows that on average the respondents that is, 41 settlers from FELDA and 45 settlers from KESEDAR obtained a total income of about RM901 to RM1200. The category of overall income of RM601 to RM900 recorded a total of 67 respondents while 31 respondents earned between RM1201m-RM1500 for both the FELDA and the KESEDAR land schemes. The income is derived fromeither their children who work, or they do Part-time work. There are also those among the settlers who run small businesses. 
Table 6. Total overall income of respondents

\begin{tabular}{llll}
\hline Total Overall Income & FELDA & KESEDAR & Total \\
\cline { 2 - 3 } & Number & Number & \\
\hline RM301 - RM600 & 20 & 31 & 51 \\
RM601 - RM900 & 34 & 33 & 67 \\
RM901 - RM1200 & 41 & 45 & 86 \\
RM1201 - RM1500 & 14 & 17 & 31 \\
RM1501 - RM1800 & 6 & 3 & 9 \\
RM2101 and above & 2 & 4 & 6 \\
Total & 117 & 133 & 250 \\
\hline
\end{tabular}

Findings showed that $67 \%$ of the total had extra income. This extra income was derived from sources such as their working children offering them money, doing business, or part-time jobs. There are many factors that influence the settlers to be involved in doing part-time jobs. Among the important factors are the sale of the farm produce is not enough to sustain themselves and their families, and their interest to do part-time work. The low income from the farm products is due to the age of the plants which has exceeded 20 years.

The study also found that respondents 80 per cent of FELDA and KESEDAR settlers in the district of Gua Musang had reached the old age of 50 years and above. At this age they are less able to work on the farm as required because their work requires energy. Thus, most of the settlers chose to hand over their farms to their children to run and some hired staff to work on their farms while some leased their farms to other individuals. They also preferred to do side jobs like small businesses to fill their free time as these jobs do not require a lot of energy.

Among the amenities provided to the KESEDAR settlers are 24 -hour electricity ( $87 \%$ of the population), clean water ( $89 \%$ of the population) and paved roads ( $80 \%$ of the population). In addition there are several facilities available for the KESEDAR community such as primary and secondary schools; health centres police stations, town hall, mosque, kindergarten and so on.

\section{Conclusion}

In general, the income level of the settlers is still low although, most of their income is above the poverty level. The main factors affecting the income of the settlers are the old age of the trees, the advanced age of many of the settlers and the land area for crops is not increasing. However, many efforts are being made by the KESEDAR and FELDA agencies to improve the lives of the settlers.

In KESEDAR's effort to encourage growth, Rural Area Small Industries which are advanced and competitive, and several types of assistance have been provided. The scheme, called the Settler Economy Fund Loan Scheme (TEKP), provides loans to residents of South Kelantan to increase their income through business activities. TEKP loans can be taken by individuals or cooperatives to provide revolving capital for business. The total funding available from the scheme is up to RM5, 000. In addition, KESEDAR in collaboration with Bank Pertanian Malaysia (BPM) had also introduced two other loan schemes in 1995; the Loan Assistance Scheme for Rural Industries (ILB) and the Economic Side Assistance Loan (ES). In addition, there are several other programmes to increase the income of the settlers as well as eradicate poverty.

To help improve the lives of the settlers and make them middle class citizens, FELDA always provides various assistance and loan facilities. Among the assistance provided by FELDA are funds the welfare of the settlers, housing loan fund, and loan schemes for the purchase of shares of FELDA Capital Cooperative (KPF), computer loan scheme for settlers.

\section{References}

Abdullah, H. (1984). Low-income life and poverty. Bangi: Universiti Kebangsaan Malaysia.

Abdullah, N. (1990). Land reform and land use programs in Malaysia. Petaling Jaya: Dewan Pustaka Islam.

Ali, S. H. (1978). Land hunger and poverty in Kelantan. Petaling Jaya: ABADI Publication.

Ayob, A. M. (1978). The Agricultural Development: Economics, Policy and Empirical Evidence. Kuala Lumpur: 
Dewan Bahasa dan Pustaka.

Dakian, M. (2008). Memerangi kemiskinan tegar. Kuala Lumpur: Dewan Ekonomi, pp. 44-47.

FELDA. (1986). FELDA Annual Report 1986. Kuala Lumpur: FELDA Publication.

FELDA. (2000). FELDA Annual Report 2000. Kuala Lumpur: FELDA Publication.

Ibrahim, Y. (1994). Rural industrialization process: the impact on community in FELDA's land schemes. Bangi: Universiti Kebangsaan Malaysia.

Khairuddin \& Giak, O. (1984). Socio-economic research. Kuala Lumpur: Dewan Bahasa dan Pustaka.

Lim, T. G. (1977). Peasants and their agricultural economy in Colonial Malaya 1874-1941. Kuala Lumpur: Oxford University Press.

Ming, K. K., \& Chandramohan, D. (2002). Malaysia palm oil industry at crossroads and its future direction. Oil Palm Industry Economic Journal, 2(2), 10-15.

Ness, G. D. (1967). Bureaucracy and rural development in Malaysia; A study of complex organisations in stimulating economic development in new states. Berkeley: University of California Press.

Omar, I., Ismail, A., \& Chong, C. L. (2001). Improving Productivity: The Replanting Imperative. Oil Palm Industry Economic Journal, 1, 22-27.

Shamsul, T. (1984). Basic problems, poverty and policy recommendations. Pulau Pinang: Consumers Association of Penang.

Smith. (1963). Microeconomics. Department of Economics. Evanston: Northwestern University.

Silcock, T. H. (1967). The Promotion of Industry and the Planning Process in Thailand: Social and Economic Studies in Development. Canberra: Australian University Press.

Todaro, M. P. (1997). Economic development (6th ed.). New York University, NY: Longman.

Za'ba. (1975). Footprints on sand of time: The Malay poverty concept over fifty years from Za'ba to Aziz.In Stephen, C. \& Khoo (eds.). Malaysian Economic Development and Politics. Kuala Lumpur: Yayasan Anda Press. 